\title{
THE HARMONIC COMPOSITION OF CURRENT IN ZERO-WORKING WIRE WITH NON-LINEAR LOAD
}

\author{
IgOR V. YUdAeV ${ }^{*}$, EVGENY V. RUD ${ }^{2}$, MIKHAIL A. YUNDIN ${ }^{3}$, \\ TAMARA Z. PONOMARENKO ${ }^{2}$ AND ALEKSANDRA M. ISUPOVA ${ }^{3}$ \\ ${ }^{I}$ Department of Thermal Engineering and Information Management System, \\ Azov-Black Sea Engineering Institute of Don State Agrarian University, \\ Zernograd, Russian Federation \\ ${ }^{2} I C P E$ "Energy Institute for Advanced Studies of the PJSC "Kubanenergo", \\ Krasnodar, Russian Federation \\ ${ }^{3}$ Department of Electric Power and Electrical Engineering, \\ Azov-Black Sea Engineering Institute of Don State Agrarian University, \\ Zernograd, Russian Federation \\ *Corresponding author: yudaev5303@ubogazici.in
}

(Received: $4^{\text {th }}$ August 2020; Accepted: $14^{\text {th }}$ October 2020; Published on-line: $4^{\text {th }}$ January 2021)

\begin{abstract}
The purpose of this study was experimental investigations and a study of the nature of the change in the main harmonic components of the current in the neutral working wire of a three-phase four-wire network with a voltage of $0.38 \mathrm{kV}$. The study of the amplitude-phase-frequency characteristics of currents flowing in an electric network with a predominant non-linear load is one of the most urgent tasks, the solution of which will increase the efficiency of electric power transmission and eliminate the negative consequences due to the current flow in a zero-working wire in the network at $0.38 \mathrm{kV}$. To study the effect of load changes on the amplitude-phase-frequency characteristics of currents in the linear and zero working wires at the input of the load node, measurements were carried out by certified electrical measuring instruments namely, the "ResourceUF2M" and "Hioki 3196". With these devices, the phase voltages at the input to the load node were measured. The analysis of the results obtained for the load node whose power was formed mainly by a lighting system with fluorescent and LED lamps and a system of office electrical receivers (computers, copiers, printers, scanners, etc.) was performed. It can be concluded that a current comparable to the currents of the linear wires of the network flows from the load node with the predominant nonlinear power receivers through the zero-working wire. At the same time, in the zero-working wire of the network, the third harmonic current prevails over the main frequency currents.
\end{abstract}

ABSTRAK: Tujuan kajian ini adalah penyelidikan eksperimental dan kajian mengenai sifat perubahan komponen harmonik utama arus dalam wayar kerja neutral rangkaian empat wayar tiga fasa dengan voltan $0.38 \mathrm{kV}$. Kajian mengenai ciri-ciri frekuensiamplitud-fasa arus yang mengalir dalam rangkaian elektrik dengan beban bukan linear yang dominan adalah salah satu tugas yang paling mendesak, penyelesaiannya akan meningkatkan kecekapan penghantaran tenaga elektrik dan menghilangkan akibat negatif yang disebabkan ke arus semasa dalam wayar sifar bekerja di rangkaian pada $0.38 \mathrm{kV}$. Untuk mengkaji kesan perubahan beban pada ciri frekuensi-fasa frekuensi arus dalam wayar linier dan sifar pada input nod beban, pengukuran dilakukan oleh alat pengukur elektrik yang disahkan iaitu, "Resource-UF2M" dan "Hioki 3196". Dengan peranti ini, voltan fasa pada input ke simpul beban diukur. Analisis hasil yang diperoleh untuk simpul beban yang kekuatannya dibentuk terutama oleh sistem pencahayaan dengan lampu pendarfluor dan LED dan sistem penerima elektrik pejabat (komputer, mesin fotokopi, pencetak, pengimbas, dll.). Dapat disimpulkan bahawa arus yang setanding dengan arus 
wayar linier rangkaian mengalir dari nod beban dengan penerima kuasa bukan linier yang dominan melalui wayar sifar. Pada masa yang sama, dalam wayar sifar rangkaian, arus harmonik ketiga berlaku berbanding arus frekuensi utama.

KEYWORDS: three-phase four-wire network; zero working wire of the network; harmonic currents; non-symmetry; non-linear power receiver

\section{INTRODUCTION}

The main reasons for current appearance in the zero-working wire of a three-phase fourwire network are the asymmetry of the loads in the phases and presence of nonlinear power receivers. When flowing through a zero-working wire, the components of the currents of higher harmonics and asymmetries cause additional losses of voltage and electricity; reduction in the service life of cable lines; increase the resistance of grounding devices of electrical installations; and interference in low-voltage communication lines [1-6].

The study of the amplitude-phase-frequency characteristics of currents flowing in an electric network with a predominant non-linear load is one of the most urgent tasks, the solution of which will increase the efficiency of electric power transmission and eliminate the negative consequences due to the current flow in a zero-working wire in the network at $0.38 \mathrm{kV}$ [7].

Since the spectral composition of currents in real electric networks is influenced by a large number of simultaneously influencing factors (the composition of power receivers in the load node, their connection diagram, switching frequency, etc.), the study of the harmonic composition of currents of the most common typical consumers is of practical interest. The power of the load node under study was formed mainly by a lighting system with fluorescent and LED lamps and a system of office electrical receivers (computers, copiers, printers, scanners, etc.) [8].

To study the effect of load changes on the amplitude-phase-frequency characteristics of currents in linear and zero working wires at the input of the load node, measurements were carried out by certified electrical measuring instruments [9]. The "Resource-UF2M" and "Hioki 3196" devices controlled currents in linear and zero working ("Hioki 3196") wires. At the same time, the same devices measured the phase voltages at the input to the load node.

\section{CHARACTERISTICS OF THE DISTORTION COEFFICIENT OF THE SINE CURVE IN ACCORDANCE WITH DAILY CHANGES}

The change in the total active power at the input of the load node during the day is shown in Fig. 1. The range of changes in the total active power is large - from $5 \mathrm{~kW}$ at night up to $68 \mathrm{~kW}$ during the day. The greatest loads were during daylight hours from 7:30 to 17:00 hours. The minimum value of the total active power, as seen in Fig. 1, was recorded in the morning (from 5:00 to 7:00 hours), and the maximum - in the daytime from 12:00 to 13:32 hours. As can be seen from Fig. 1, the power consumption of the load node occurred according to a two-stage schedule. 


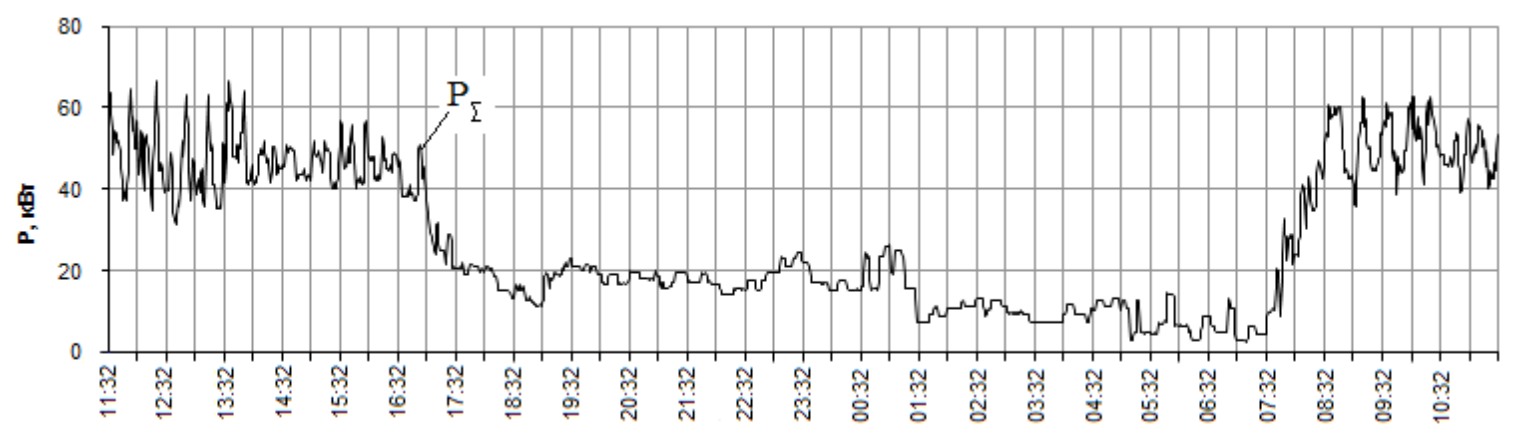

Fig. 1: Schedule of changes in total active power at the input of the load node.

Moreover, the change in active capacities during the day is very asymmetric in the network phases (Fig. 2). The active power P1 of the first phase L1 during the day turned out to be the smallest most of the time. Separate bursts of active power P1 of phase L1 were clearly observed in the period from 5:00 to 6:00 hours, when the load was the greatest. Most of the day, the greatest load fell on the L3 phase with an active power of P3. Only in the period from 14:00 to 16:32 hours the active power of P2 exceeded P3.

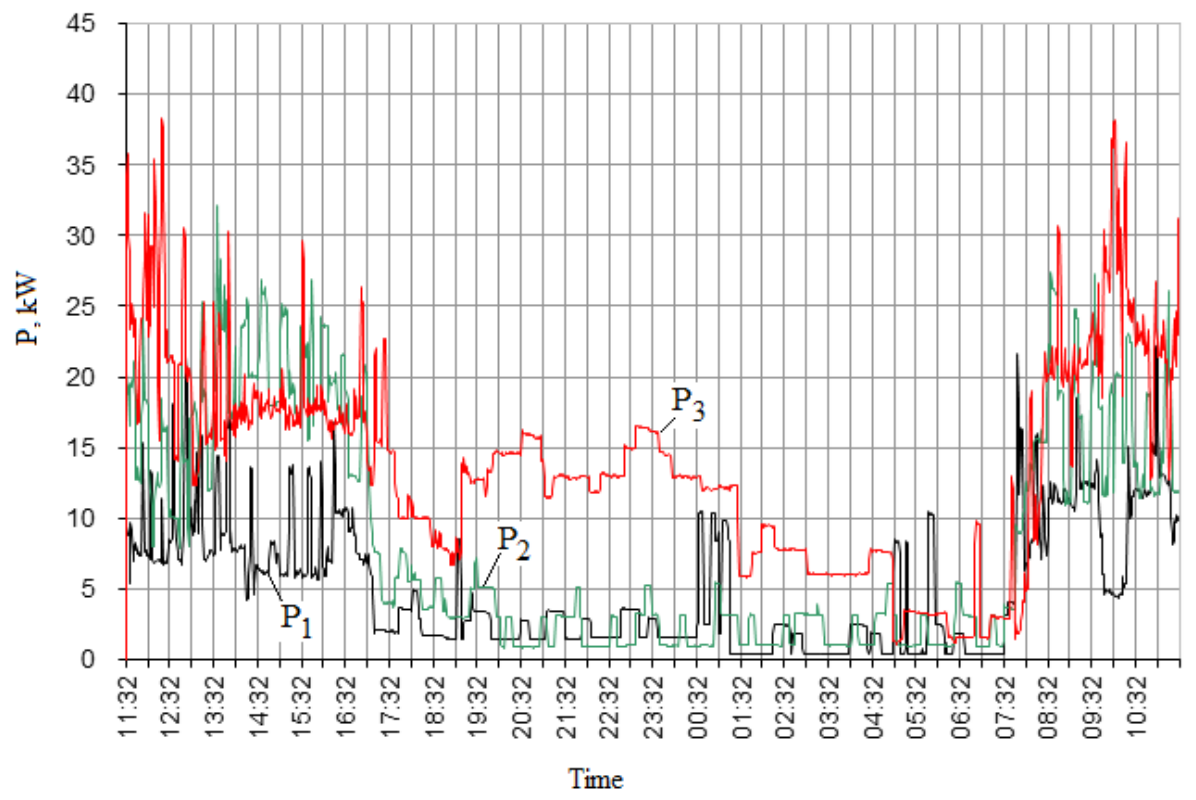

Fig. 2: Daily graphs of changes in active powers for the phases of the network $0.38 \mathrm{kV}$ at the input of the load node.

Due to the asymmetric load of the phases, the voltage asymmetry coefficients in the zero and reverse sequences of the fundamental frequency were significant (Fig. 3). So, for example, the voltage asymmetry coefficient in the zero sequence of the fundamental frequency $\left(\mathrm{K}_{0 U}\right)$ did not fall during the day, even with a minimum (below 2\%) load. During periods of greatest power consumption (from 8:00 to 17:00 hours), the voltage unbalance coefficient in the zero sequence of the fundamental frequency often exceeded $5 \%$.

The voltage asymmetry coefficient in the reverse sequence of the fundamental frequency $\left(\mathrm{K}_{2 U}\right)$ during the day had lower values. Moreover, it turned out to be more stable than the coefficient $\mathrm{K}_{0 U}$. The range of variation of $\mathrm{K}_{2 U}$ ranged from $2 \%$ to $4 \%$. The results of these studies, as well as an analysis of literature [10-15] indicate that the active use of switching power supplies in electrical appliances leads to an increase in harmonic distortions of voltages and currents in the electrical network. Moreover, the distortion coefficients of 
the sinusoidality of the voltages have lower values than the distortion coefficients of the sinusoidality of the load currents.

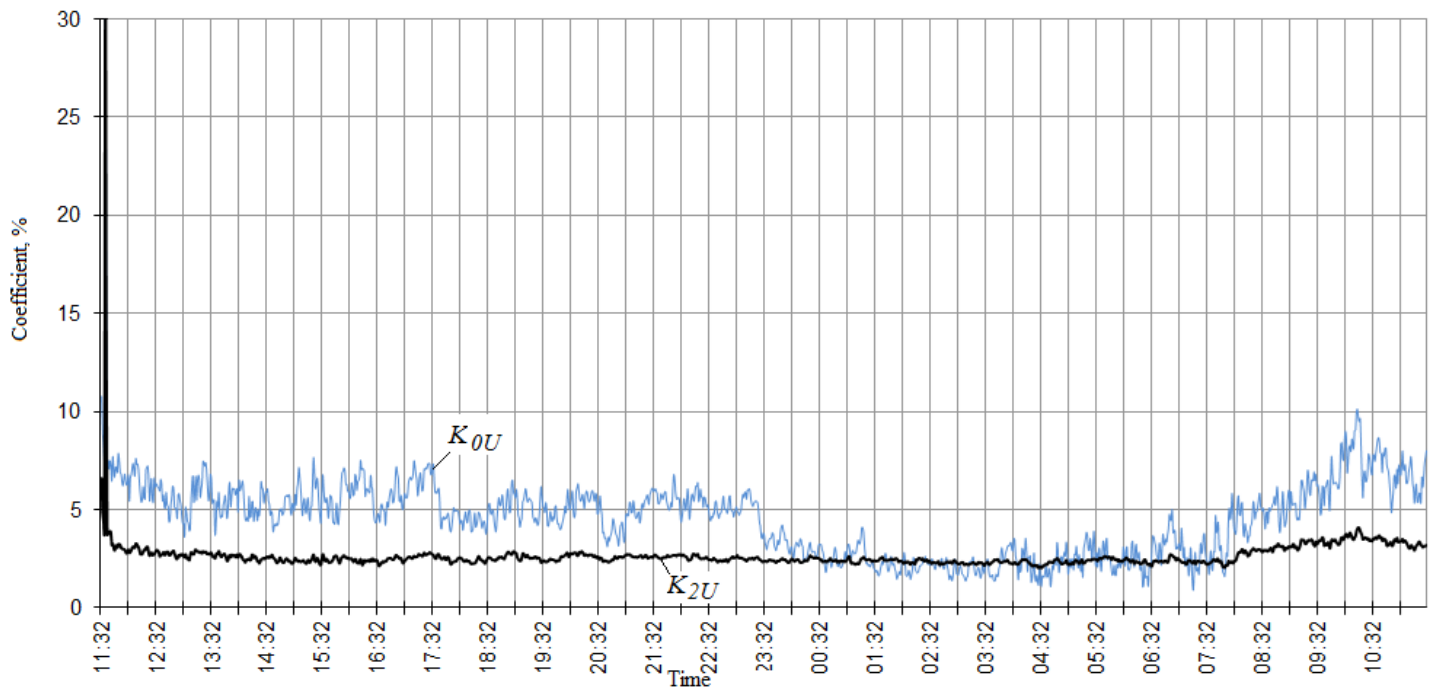

Fig. 3: Diagrams of daily changes in the voltage asymmetry coefficients in the zero and reverse sequence at the input of the load node with the prevailing non-linear power receivers.

Figure 4 shows graphs of daily changes in the distortion coefficients of the sinusoidality of the voltage curves in the phases of the network at the input of the load node $0.38 \mathrm{kV}$. It should be noted that in none of the phases at the input of the load node, the distortion coefficient of the sinusoidality of the voltage curves did not exceed the minimum allowable value $-8 \%$.

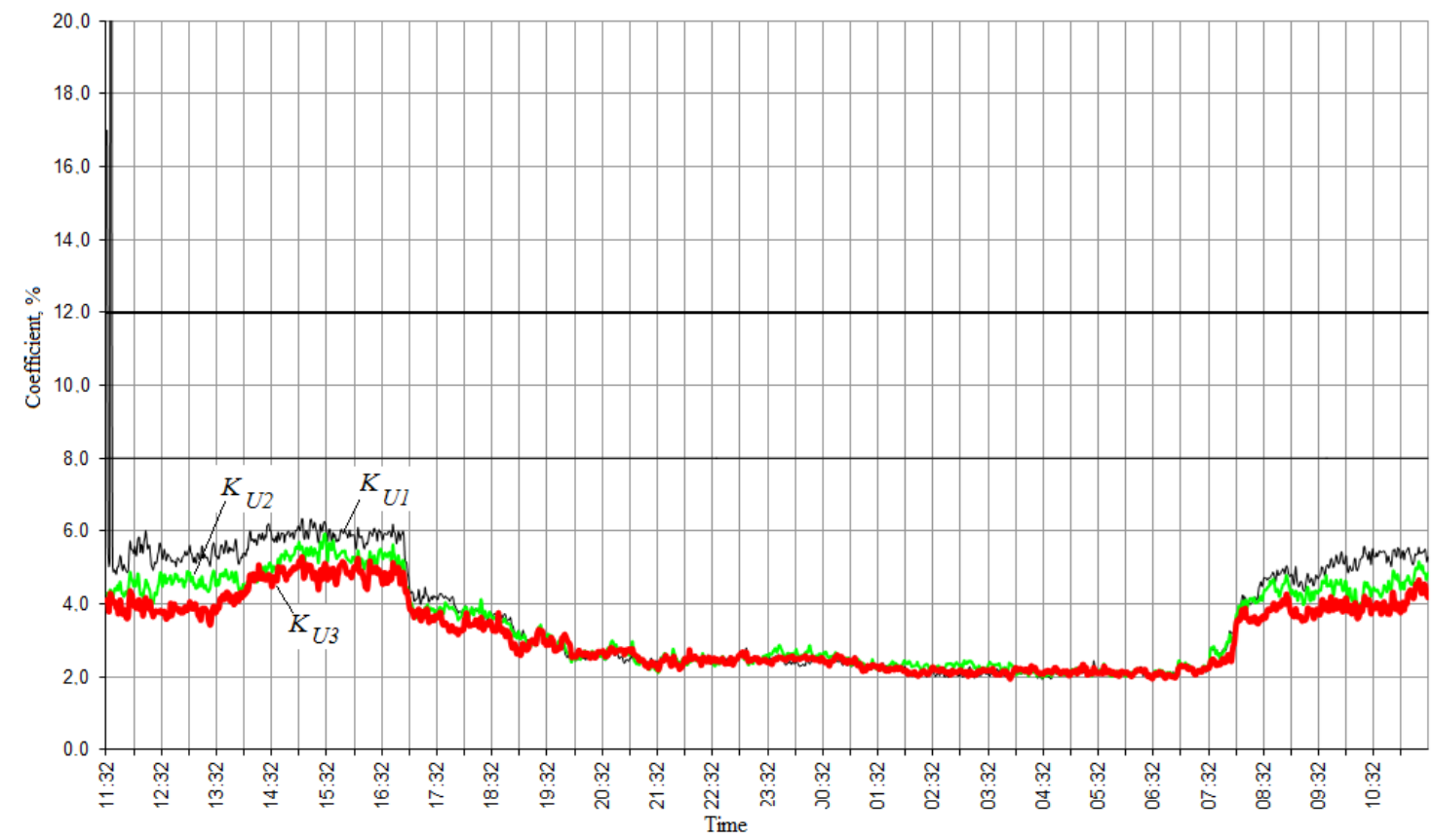

Fig. 4: Diagrams of daily changes in the distortion coefficients of the sinusoidality of the phase voltage curves at the input of the load node with predominant nonlinear power receivers. 
During periods of maximum load (from 8:00 to 17:00 hours), the distortion coefficient of the sinusoidality of the voltage curve in the first phase $K_{U 1}$ was the largest, more than $6 \%$ (see Fig. 4). During load shedding, the distortion coefficients of the sinusoidality of the voltage curves in phases became the same (over $2 \%$ ). The average amplitude-frequency characteristic of the most significant average daily coefficients of the 3rd, 5th, 7th, 9th and 11th voltage harmonics in the phases of the network $0.38 \mathrm{kV}$ at the input to the load node (Fig. 5) clearly show that the odd harmonic voltage components prevail over even ones.

Among the odd higher voltage harmonics, the 3rd, 5th, and 9th harmonics had the largest amplitudes. It should be noted that the largest amplitudes of the 3rd and 5th voltage harmonics were recorded in the first phase, and the 9th voltage harmonic was the largest in the second phase of the network $0.38 \mathrm{kV}$ (Fig. 5). The coefficients of the 3rd voltage harmonic by phase at the input to the load node varied from $4.7 \%$ to $5.5 \%$, the coefficients of the 5 th voltage harmonic, respectively, from $1.4 \%$ to $2.5 \%$, and the coefficients of the 9 th voltage harmonic, respectively, from $1.0 \%$ to $1.4 \%$ (Fig. 5).

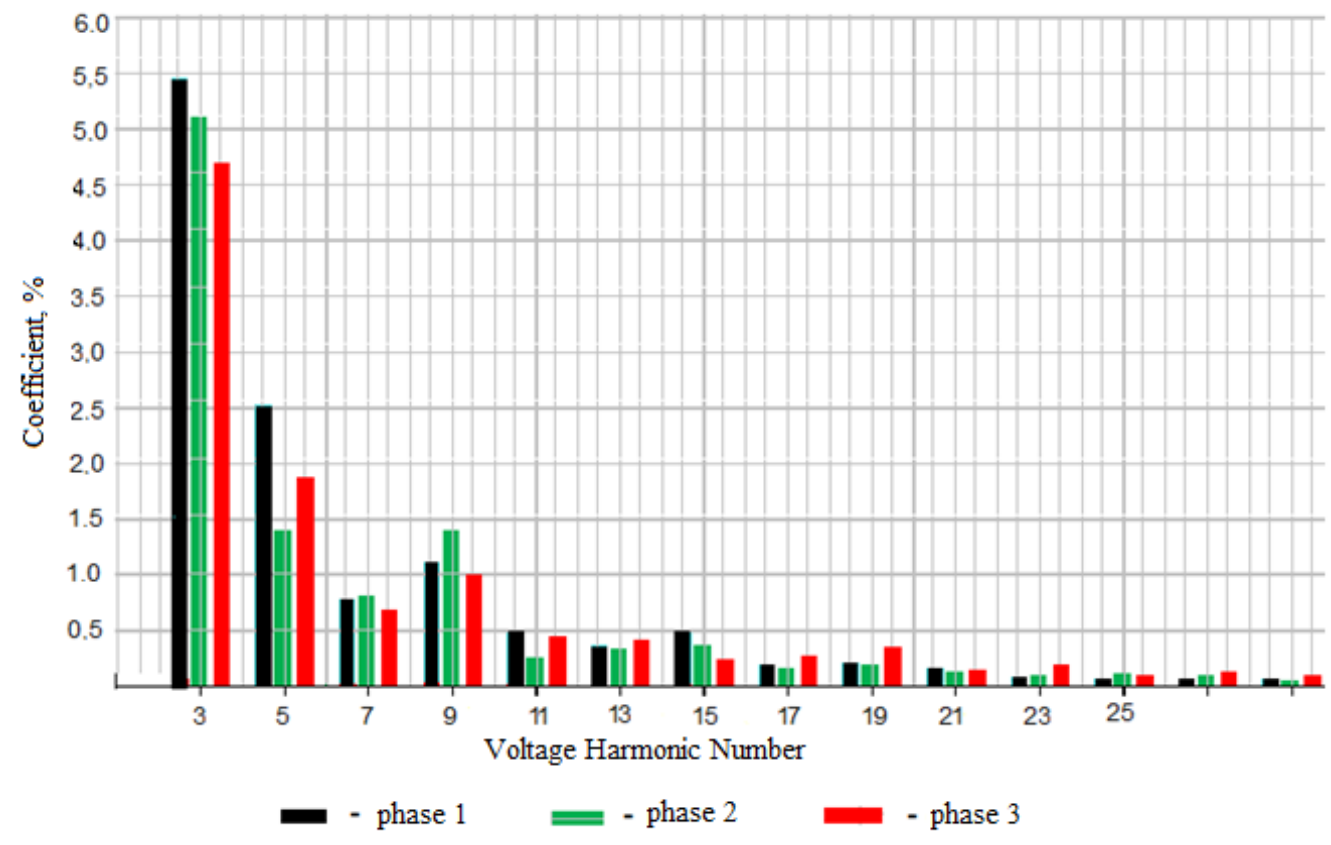

Fig. 5: Frequency response of the most significant daily average coefficients of the $n$-th harmonic components of the phase voltage at the input of the load node.

\section{CHANGES IN CURRENT PARAMETERS AT VARIOUS LOADS OF THE POWER RECEIVER}

To assess the degree of distortion of currents sinusoidality during the period of the highest loads, the waveforms of the phase currents and in the zero-working wire at the input of the load node were recorded using the "Hioki 3196" instrument (Fig. 6).

The current waveforms correspond to the time interval on the daily graph of the change in the total active power at the highest load (from 11:40 to 12:00 hours according to the schedule of Fig. 1). An analysis of the current shape in the zero-working wire $i_{4}(t)$ on the waveform shows (Fig. 6) that it is not substantially sinusoidal. The waveforms of currents in the linear wires of the load node $i_{1}(t), i_{2}(t)$ and $i_{3}(t)$ are also significantly distorted by higher harmonics. 


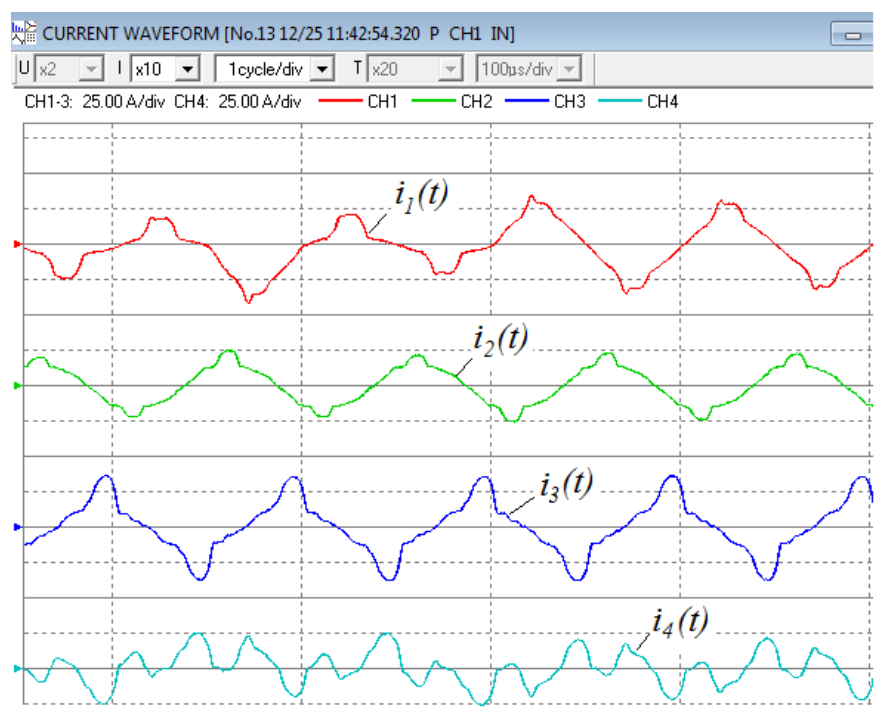

Fig. 6: A fragment of the waveforms of the phase currents and the zero-working wire at the input of the load node with the prevailing non-linear power receivers.

Using the "Hioki 3196" software package, the amplitudes and phases of the currents were determined for seven significant harmonic components not equal to zero (odd harmonics from the 1 st to the 13th). For compact recordings, these transformations are presented in the form of Fig. 7, which also shows mathematical models (expressions) of instantaneous current values at the input to the load node.

In Fig. 7, the Fourier expansion is performed up to the 50th harmonic of the current. This allows us to justify the selection of the seven most significant harmonic components of the current by comparison. The sinusoidal distortion coefficients of the curves (see Fig. 7) are denoted by THD (Total Harmonic Distortions) and are called the "total current harmonic distortion coefficient".

As can be seen from Fig. 5, the values of the sinusoidality distortion coefficients of the current curves THDI1, THDI2 and THDI3 significantly exceed the similar voltage coefficients. In the first linear wire L1 at the input of the load node, the total THDI current distortion factor for the considered time was $23.7 \%$, in the second wire L2 $-15.98 \%$, in the third wire L3 $-36.18 \%$, and in the neutral wire $-138.35 \%$, respectively.

The analysis of the harmonic composition of the current of the zero-working wire i4(t) is of interest. As can be seen from Fig. 1, in the working (mean square) current I4, the proportion of the main harmonic of the current is $6.77 \mathrm{~A}$. The proportion of the third harmonic components of the currents flowing in the linear wires of the network $0.38 \mathrm{kV}$, in the zero working wire for the considered time point, is $8.9 \mathrm{~A}$, in 5 th harmonic current, respectively, $2.33 \mathrm{~A}, 7$ th $-0.79 \mathrm{~A}, 9$ th $-1.13 \mathrm{~A}, 11$ th $-0.51 \mathrm{~A}$ and 13 th $-0.58 \mathrm{~A}$. In this case, the total current load of the zero-working wire for the considered time was equal to $12.48 \mathrm{~A}$.

With this load mode, the current values in the linear wires of the network $0.38 \mathrm{kV}$ were as follows: $\mathrm{I} 1=16.63 \mathrm{~A} ; \mathrm{I} 2=13.54 \mathrm{~A}$; $\mathrm{I} 3=18.8 \mathrm{~A}$. That is, the current load of the zero working wire is commensurate with the load of the linear wires. Obviously, the third and ninth current harmonics make the main contribution to the increase in the current load of the zero-working wire to the values of the currents flowing in the linear wires of the network $0.38 \mathrm{kV}$. 
(a)

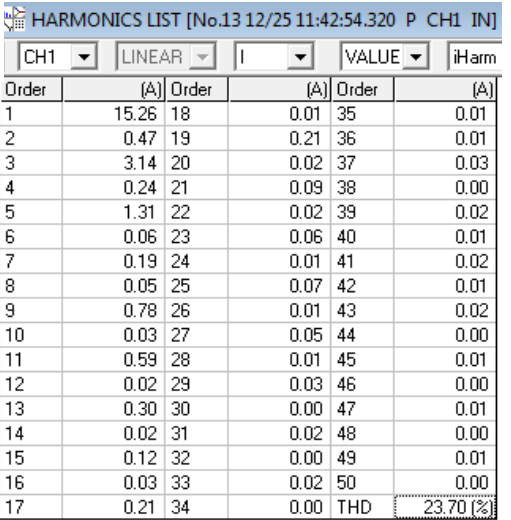

(c)

Injer HARMONICS LIST [No.13 12/25 11:42:54.320 P CH1 IN]

\begin{tabular}{|c|c|c|c|c|c|c|c|}
\hline $\mathrm{CH} 2$ & $\nabla$ & LINE. & $\mathrm{AR} \quad$ & 1 & 7 & VALL & - iHarm \\
\hline Order & & & Order & & (A) & Order & (A) \\
\hline 1 & & 13.34 & 18 & & 0.02 & 35 & 0.05 \\
\hline 2 & & 0.11 & 19 & & 0.14 & 36 & 0.01 \\
\hline 3 & & 1.34 & 20 & & 0.01 & 37 & 0.02 \\
\hline 4 & & 0.10 & 21 & & 0.06 & 38 & 0.00 \\
\hline 5 & & 1.22 & 22 & & 0.01 & 39 & 0.01 \\
\hline 6 & & 0.06 & 23 & & 0.09 & 40 & 0.01 \\
\hline 7 & & 0.86 & 24 & & 0.01 & 41 & 0.04 \\
\hline 8 & & 0.04 & 25 & & 0.11 & 42 & 0.01 \\
\hline 9 & & 0.47 & 26 & & 0.01 & 43 & 0.01 \\
\hline 10 & & 0.04 & 27 & & 0.05 & 44 & 0.01 \\
\hline 11 & & 0.09 & 28 & & 0.02 & 45 & 0.02 \\
\hline 12 & & 0.02 & 29 & & 0.07 & 46 & 0.00 \\
\hline 13 & & 0.30 & 30 & & 0.01 & 47 & 0.02 \\
\hline 14 & & 0.02 & 31 & & 0.02 & 48 & 0.01 \\
\hline 15 & & 0.26 & 32 & & 0.00 & 49 & 0.01 \\
\hline 16 & & 0.02 & 33 & & 0.03 & 50 & 0.00 \\
\hline 17 & & 0.17 & 34 & & 0.01 & THD & $15.98 \%$ \\
\hline
\end{tabular}

(e)

Uh: HARMONICS LIST [No.13 12/25 11:42:54.320 P CH1 IN] CH3 - LINEAR

\begin{tabular}{|l|r|r|r|r|r|}
\hline Order & $(\mathrm{A})$ & Order & $(\mathrm{A})$ & Order & $(\mathrm{A})$ \\
\hline 1 & 17.63 & 18 & 0.01 & 35 & 0.02 \\
\hline 2 & 0.06 & 19 & 0.16 & 36 & 0.01 \\
\hline 3 & 5.20 & 20 & 0.01 & 37 & 0.03 \\
\hline 4 & 0.06 & 21 & 0.22 & 38 & 0.00 \\
\hline 5 & 3.26 & 22 & 0.01 & 39 & 0.02 \\
\hline 6 & 0.03 & 23 & 0.13 & 40 & 0.00 \\
\hline 7 & 1.08 & 24 & 0.01 & 41 & 0.01 \\
\hline 8 & 0.04 & 25 & 0.10 & 42 & 0.00 \\
\hline 9 & 0.72 & 26 & 0.01 & 43 & 0.01 \\
\hline 10 & 0.03 & 27 & 0.12 & 44 & 0.01 \\
\hline 11 & 0.68 & 28 & 0.01 & 45 & 0.01 \\
\hline 12 & 0.02 & 29 & 0.09 & 46 & 0.00 \\
\hline 13 & 0.69 & 30 & 0.01 & 47 & 0.01 \\
\hline 14 & 0.02 & 31 & 0.06 & 48 & 0.00 \\
\hline 15 & 0.44 & 32 & 0.01 & 49 & 0.01 \\
\hline 16 & 0.02 & 33 & 0.05 & 50 & 0.00 \\
\hline 17 & 0.20 & 34 & 0.01 & THD & $36.18[\%]$ \\
\hline
\end{tabular}

(g)

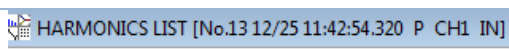

\begin{tabular}{|c|c|c|c|c|c|}
\hline $\mathrm{CH} 4$ & $=\quad$ LINE & $\overline{A R} \quad$ & $\nabla$ & VALL & iHarm \\
\hline Order & & Order & (A) & Order & (A) \\
\hline 1 & 6.77 & 18 & 0.02 & 35 & 0.04 \\
\hline 2 & 0.36 & 19 & 0.39 & 36 & 0.01 \\
\hline 3 & 8.90 & 20 & 0.01 & 37 & 0.04 \\
\hline 4 & 0.12 & 21 & 0.15 & 38 & 0.01 \\
\hline 5 & 2.33 & 22 & 0.02 & 39 & 0.03 \\
\hline 6 & 0.03 & 23 & 0.16 & 40 & 0.01 \\
\hline 7 & 0.79 & 24 & 0.02 & 41 & 0.04 \\
\hline 8 & 0.06 & 25 & 0.20 & 42 & 0.00 \\
\hline 9 & 1.13 & 26 & 0.01 & 43 & 0.02 \\
\hline 10 & 0.04 & 27 & 0.10 & 44 & 0.00 \\
\hline 11 & 0.51 & 28 & 0.01 & 45 & 0.02 \\
\hline 12 & 0.02 & 29 & 0.06 & 46 & 0.00 \\
\hline 13 & 0.59 & 30 & 0.01 & 47 & 0.01 \\
\hline 14 & 0.02 & 31 & 0.05 & 48 & 0.00 \\
\hline 15 & 0.33 & 32 & 0.01 & 49 & 0.01 \\
\hline 16 & 0.01 & 33 & 0.06 & 50 & 0.00 \\
\hline 17 & 0.12 & 34 & 0.00 & THD & 138.35 [\%) \\
\hline
\end{tabular}

Uhe HARMONICS LIST [No.13 12/25 11:42:54.320 P CH1 IN]

\begin{tabular}{|c|c|c|c|c|c|}
\hline $\mathrm{CH} 1$ & $=\quad$ LINEA & $A R=$ & $=$ & PHAS & iHarm \\
\hline Order & & Order & (") & Order & {$\left[{ }^{0}\right]$} \\
\hline 1 & 1.82 & 18 & 120.45 & 35 & 18.98 \\
\hline 2 & 53.56 & 19 & 163.86 & 36 & -177.96 \\
\hline 3 & -162.77 & 20 & -37.62 & 37 & 176.51 \\
\hline 4 & 89.29 & 21 & 17.44 & 38 & -165.05 \\
\hline 5 & 15.65 & 22 & -123.83 & 39 & -6.73 \\
\hline 6 & -81.85 & 23 & -41.41 & 40 & 76.79 \\
\hline 7 & -43.47 & 24 & 87.99 & 41 & .94 .62 \\
\hline 8 & -160.74 & 25 & 145.48 & 42 & 40.51 \\
\hline 9 & -165.38 & 26 & $\cdot 60.95$ & 43 & 118.26 \\
\hline 10 & - 62.94 & 27 & -45.67 & 44 & -164.37 \\
\hline 11 & 27.37 & 28 & -160.15 & 45 & .72 .27 \\
\hline 12 & -103.36 & 29 & 60.02 & 46 & 73.72 \\
\hline 13 & -153.29 & 30 & 20.63 & 47 & -158.52 \\
\hline 14 & 113.83 & 31 & -161.66 & 48 & -166.54 \\
\hline 15 & 125.83 & 32 & -114.75 & 49 & 57.30 \\
\hline 16 & $\cdot 75.11$ & 33 & .78 .42 & 50 & 4.29 \\
\hline 17 & $\cdot-14.53$ & 34 & 85.21 & THD & 23.70 \\
\hline
\end{tabular}

IU. HARMONICS LIST [No.13 12/25 11:42:54.320 P CH1 IN]

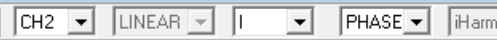

\begin{tabular}{|c|c|c|c|c|c|}
\hline Order & [0] & Order & $\left({ }^{\circ}\right)$ & Order & $\left({ }^{\circ}\right)$ \\
\hline 1 & -130.16 & 18 & -15.58 & 35 & .76 .77 \\
\hline 2 & 128.03 & 19 & 101.12 & 36 & 77.00 \\
\hline 3 & -172.50 & 20 & 90.69 & 37 & 114.93 \\
\hline 4 & 127.01 & 21 & 7.54 & 38 & -107.59 \\
\hline 5 & 87.84 & 22 & 176.82 & 39 & -144.18 \\
\hline 6 & 87.59 & 23 & 168.53 & 40 & .24 .84 \\
\hline 7 & 2.23 & 24 & .73 .38 & 41 & .73 .73 \\
\hline 8 & 65.70 & 25 & 93.07 & 42 & 43.91 \\
\hline 9 & -42.09 & 26 & 3.48 & 43 & 67.16 \\
\hline 10 & 32.59 & 27 & 13.42 & 44 & -165.22 \\
\hline 11 & 115.61 & 28 & 132.19 & 45 & 128.06 \\
\hline 12 & 76.57 & 29 & -124.31 & 46 & .93 .09 \\
\hline 13 & -0.19 & 30 & 169.24 & 47 & .75 .98 \\
\hline 14 & -111.98 & 31 & 74.02 & 48 & 54.93 \\
\hline 15 & $\cdot 63.09$ & 32 & .46 .72 & 49 & -140.87 \\
\hline 16 & -110.36 & 33 & 2.69 & 50 & .61 .99 \\
\hline 17 & -177.07 & 34 & 79.57 & THD & $15.981 \%$ \\
\hline
\end{tabular}

Uh: HARMONICS LIST [No.13 12/25 11:42:54.320 P CH1 IN]

\begin{tabular}{|c|c|c|c|c|c|}
\hline $\mathrm{CH} 3$ & - LINE & $\mathrm{AR}=$ & $\nabla$ & PHAS & i iHarm \\
\hline Order & & Order & {$[0]$} & Order & {$\left[0^{\circ}\right]$} \\
\hline 1 & 115.01 & 18 & 143.27 & 35 & 45.87 \\
\hline 2 & 126.13 & 19 & 85.28 & 36 & .85 .02 \\
\hline 3 & 156.02 & 20 & 121.57 & 37 & 40.86 \\
\hline 4 & 49.56 & 21 & 148.69 & 38 & -161.22 \\
\hline 5 & -176.53 & 22 & 69.33 & 39 & .59 .04 \\
\hline 6 & 158.52 & 23 & 150.75 & 40 & 91.53 \\
\hline 7 & -137.41 & 24 & 43.32 & 41 & 85.62 \\
\hline 8 & 141.20 & 25 & 44.48 & 42 & 85.80 \\
\hline 9 & 169.81 & 26 & 53.06 & 43 & $\cdot 7.78$ \\
\hline 10 & -125.18 & 27 & 103.08 & 44 & .43 .25 \\
\hline 11 & 166.69 & 28 & .13 .14 & 45 & .90 .98 \\
\hline 12 & -138.38 & 29 & 102.38 & 46 & -141.95 \\
\hline 13 & 161.94 & 30 & 9.53 & 47 & 57.14 \\
\hline 14 & 76.80 & 31 & 27.33 & 48 & -105.83 \\
\hline 15 & 153.35 & 32 & $\cdot 7.38$ & 49 & .71 .00 \\
\hline 16 & 128.98 & 33 & 58.05 & 50 & 110.01 \\
\hline 17 & 117.75 & 34 & .63 .44 & THD & $36.18[\%]$ \\
\hline
\end{tabular}

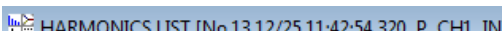

\begin{tabular}{|c|c|c|c|c|c|}
\hline \multirow{2}{*}{ 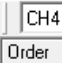 } & \multicolumn{2}{|c|}{ LINEAR $\square$} & \multirow{2}{*}{ 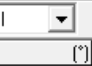 } & PHASE $=$ & \multirow{2}{*}{ i } \\
\hline & & 10 Order & & Order & \\
\hline 1 & .81 .64 & 18 & .113 .77 & 35 & 136.02 \\
\hline 2 & 122.75 & 19 & $\cdot 61.54$ & 36 & 75.87 \\
\hline 3 & $\cdot 7.41$ & 20 & -172.59 & 37 & - 91.27 \\
\hline 4 & 72.38 & 21 & $\cdot 73.85$ & 38 & 37.77 \\
\hline 5 & $\cdot 36.90$ & 22 & $\cdot 1.55$ & 39 & 128.25 \\
\hline 6 & $\cdot 37.48$ & 23 & -16.74 & 40 & 115.84 \\
\hline 7 & 102.91 & 24 & 174.55 & 41 & 99.27 \\
\hline 8 & 40.50 & 25 & .95 .85 & 42 & 161.65 \\
\hline 9 & 17.24 & 26 & -179.40 & 43 & -114.87 \\
\hline 10 & .176 .51 & 27 & .117 .63 & 44 & 12.18 \\
\hline 11 & .73 .24 & 28 & .50 .26 & 45 & 56.38 \\
\hline 12 & $\cdot 18.32$ & 29 & .52 .58 & 46 & 72.93 \\
\hline 13 & - 9.64 & 30 & 131.88 & 47 & 65.58 \\
\hline 14 & $\cdot 13.98$ & 31 & .138 .00 & 48 & 138.60 \\
\hline 15 & .11 .22 & 32 & 99.85 & 49 & 107.95 \\
\hline 16 & 82.45 & 33 & .157 .40 & 50 & .30 .81 \\
\hline 17 & - 63.08 & 34 & 160.42 & THD & $138.35 \%$ \\
\hline
\end{tabular}

(d)

(f)

(b)

(h)

Fig. 7: Vector diagrams of currents and voltages at a frequency of $150 \mathrm{~Hz}$ at the input of a load node with predominant nonlinear power consumers: 


$$
\begin{aligned}
& \text { a), b) }-i_{1}(t)=\sqrt{2} \cdot\left(\begin{array}{c}
15,26 \sin \left(\omega t+2^{\circ}\right)+3,14 \sin \left(3 \omega t-163^{\circ}\right)+ \\
+1,31 \sin \left(5 \omega t+16^{\circ}\right)+0,19 \sin \left(7 \omega t-44^{\circ}\right)+0,78 \sin \left(9 \omega t-165^{\circ}\right)+ \\
+0,59 \sin \left(11 \omega t+27^{\circ}\right)+0,30 \sin \left(13 \omega t-153^{\circ}\right)
\end{array}\right) \mathrm{A} \\
& \text { c), d) }-i_{2}(t)=\sqrt{2} \cdot\left(\begin{array}{c}
13,34 \sin \left(\omega t-130^{\circ}\right)+1,34 \sin \left(3 \omega t-173^{\circ}\right)+ \\
+1,22 \sin \left(5 \omega t+88^{\circ}\right)+0,86 \sin \left(7 \omega t+2^{\circ}\right)+0,47 \sin \left(9 \omega t-42^{\circ}\right)+ \\
+0,09 \sin \left(11 \omega t+116^{\circ}\right)+0,30 \sin \left(13 \omega t-0^{\circ}\right)
\end{array}\right) \text { A } \\
& \text { e), f) }-i_{3}(t)=\sqrt{2} \text {. } \\
& \left(\begin{array}{c}
17,63 \sin \left(\omega t+115^{\circ}\right)+5,20 \sin \left(3 \omega t+156^{\circ}\right)+ \\
+3,26 \sin \left(5 \omega t-177^{\circ}\right)+1,08 \sin \left(7 \omega t-137^{\circ}\right)+0,72 \sin \left(9 \omega t+164^{\circ}\right)+ \\
+0,68 \sin \left(11 \omega t+167^{\circ}\right)+0,69 \sin \left(13 \omega t+162^{\circ}\right)
\end{array}\right) \mathrm{A} \\
& \mathrm{g}), \mathrm{h})-i_{4}(t)=\sqrt{2} \cdot\left(\begin{array}{c}
6,77 \sin \left(\omega t-82^{\circ}\right)+8,90 \sin \left(3 \omega t-7^{\circ}\right)+ \\
+2,33 \sin \left(5 \omega t-37^{\circ}\right)+0,79 \sin \left(7 \omega t+103^{\circ}\right)+1,13 \sin \left(9 \omega t+17^{\circ}\right)+ \\
+0,51 \sin \left(11 \omega t-73^{\circ}\right)+0,59 \sin \left(13 \omega t-10^{\circ}\right)
\end{array}\right) \mathrm{A}
\end{aligned}
$$
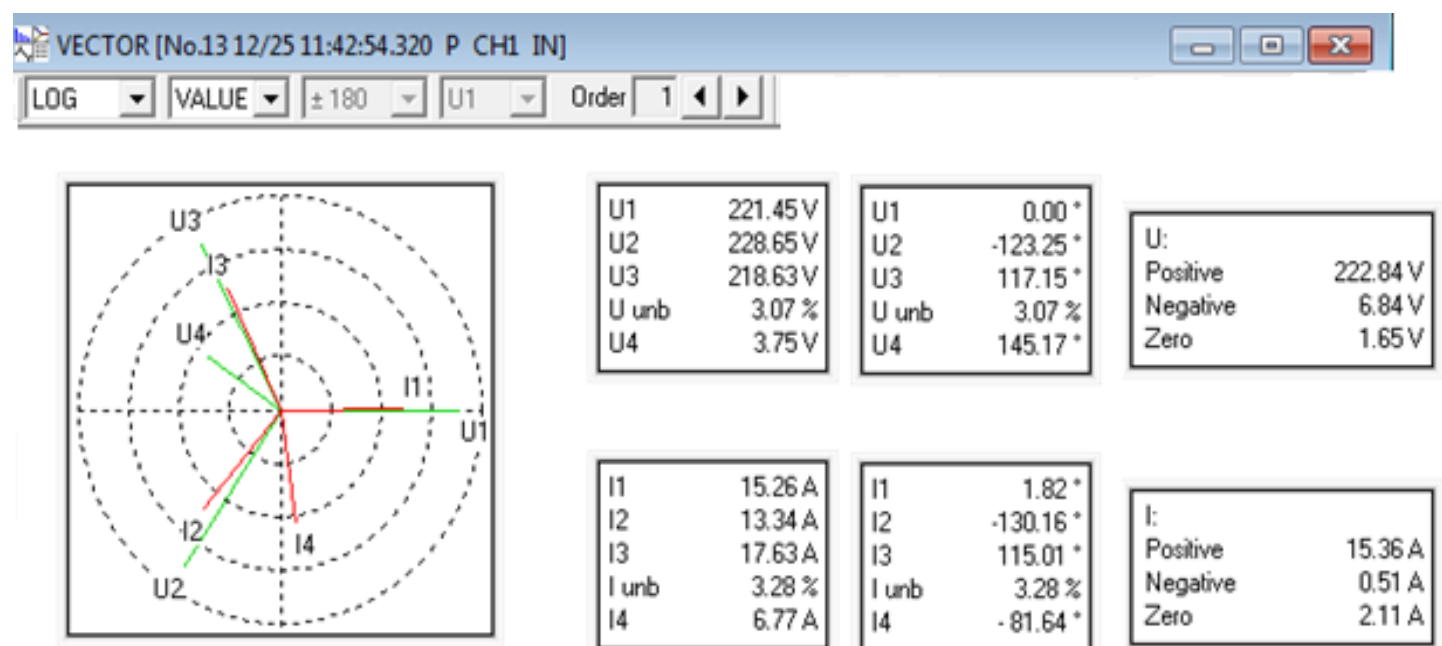

\begin{tabular}{|lr|}
\hline$I 1$ & $15.26 \mathrm{~A}$ \\
\hline 2 & $13.34 \mathrm{~A}$ \\
\hline 13 & $17.63 \mathrm{~A}$ \\
\hline I unb & $3.28 \%$ \\
\hline 14 & $6.77 \mathrm{~A}$ \\
\hline
\end{tabular}

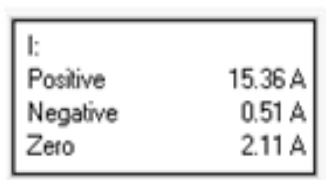

Fig. 8: Vector diagrams of currents and voltages at a frequency of $50 \mathrm{~Hz}$ at the input of a load node with predominant nonlinear power consumers.

Figure 8, obtained using the "HIOKI 3196" instrument software, shows the logical vector diagrams of currents and voltages at the input of the load node with prevailing nonlinear power receivers at time 11:42 (see Fig. 1). Along with this, the amplitude of the third harmonic of the current $i_{4}(t)$ is greater than the amplitude of the fundamental harmonic.

In addition to the current values of voltage and current, the phase shifts of each value are also indicated here. For the first harmonic (frequency $50 \mathrm{~Hz}$ ) the components of the direct (Positive), reverse (Negative) and zero (Zero) sequences of voltages and currents are given. With these components, real three-phase voltage and current systems can be balanced to a symmetrical system. Similar characteristics for the considered time and frequency of $150 \mathrm{~Hz}$ are presented in Fig. 9.

A distinctive feature of the vector diagrams of voltages and currents of the third harmonic (Fig. 9) is the lack of common mode between the vectors of different phases. Along with the lack of phase matching of vectors, they are also characterized by inequality in magnitude. So, for example, the effective current of the third harmonic in the first phase is $3.14 \mathrm{~A}$, in the second phase is $1.34 \mathrm{~A}$, and in the third phase is $5.2 \mathrm{~A}$ (see Fig. 1). This is 
explained by the nature of the formation of these currents in the load node in case of accidental switching on of various power consumers under different voltages.
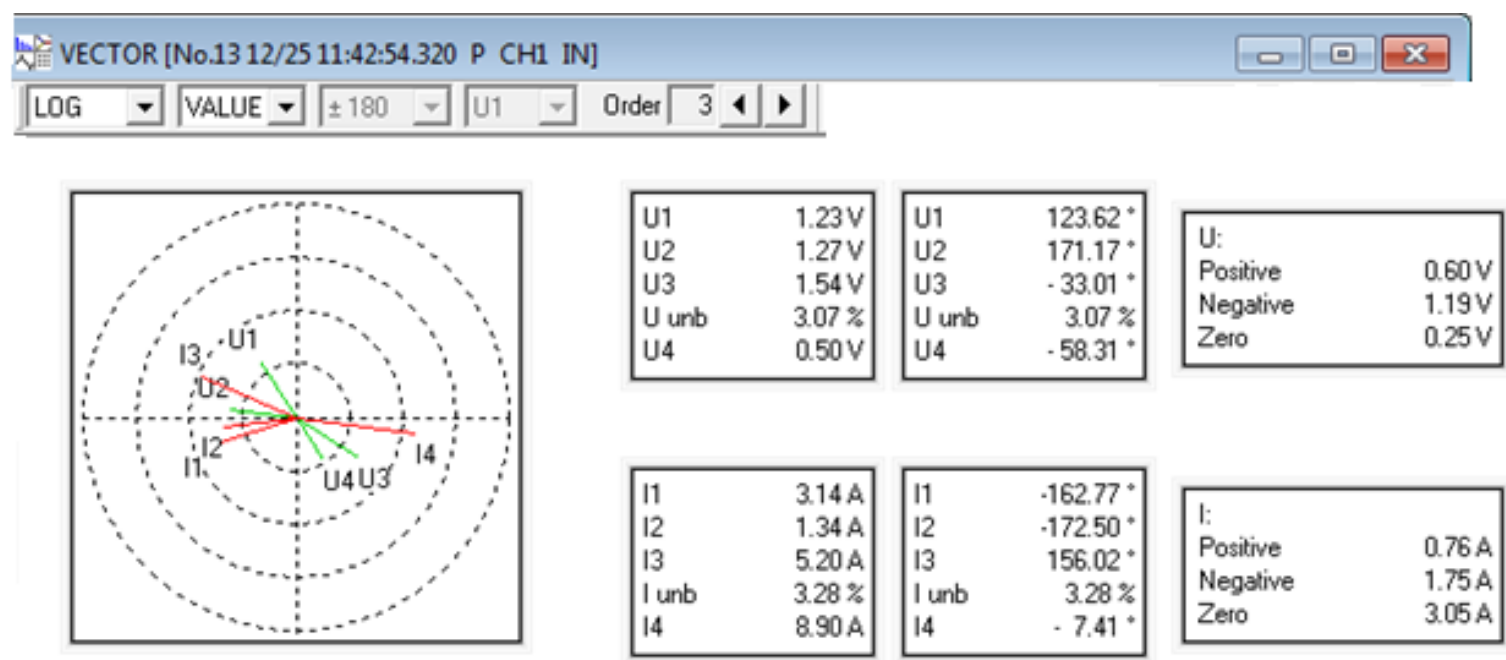

Fig. 9: Vector diagrams of currents and voltages at a frequency of $150 \mathrm{~Hz}$ at the input of a load node with predominant nonlinear power consumers.

\section{CONCLUSIONS}

The research contribution of this work lies in the fact that an experimental study was carried out, the nature of the change in the fundamental harmonic components of the current in the zero-working wire of a three-phase four-wire network with a voltage of $0.38 \mathrm{kV}$ was studied. The results obtained during the work will increase the efficiency of electric power transmission and eliminate the negative consequences due to the current flow in a zeroworking wire in the network $0.38 \mathrm{kV}$.

The analysis of the research results shows that in the presence of non-linear power receivers, the current in the zero-working wire of a three-phase four-wire network is comparable with the currents in linear wires. So, in the maximum load mode, with the current value of the zero working wire current $12.48 \mathrm{~A}$, the currents of the linear wires were $I_{1}=16.63 \mathrm{~A}, I_{2}=13.54 \mathrm{~A}$, and $I_{3}=18.8 \mathrm{~A}$, respectively.

Based on the obtained results of the study, it can be argued that the currents of the third harmonic component, which dominate in the neutral working wire of the network $0.38 \mathrm{kV}$, are not in-phase in the linear wires. The results obtained are of great practical importance when designing technical means that provide current unloading of the zero-working wire of the network $0.38 \mathrm{kV}$ and, ultimately, reduce energy losses during transmission.

\section{REFERENCES}

[1] Grigoriev OA, Petukhov VS, Sokolov VA, Krasilov IA. (2003) On the impact of electronic equipment on power networks. Computer Press, 1. Retrieved from http://www.compress.ru/article. aspx?id=9553\&iid=404.

[2] Om PM, Abdul GSh, Neeraj G. (2015) Acritical review of detection and classification of power quality events. Renewable \& Sustainable Energy Reviews, 41: 495-505.

[3] Daus YV, Yudaev IV, Taranov MA, Voronin SM, Gazalov VS. (2019) Reducing the costs for consumed electricity through the solar energy utilization. International Journal of Energy Economics and Policy, 9(2): 19-23. 
[4] Ded AV. (2017) To the problem of the current state of the levels of indices of asymmetry of voltages and currents in networks of 0.4 kV. Omsk Scientific Herald, 2(152): 63-65.

[5] Kosoukhov FD, Vasiliev NV, Kuznetsova ES. (2017) New scientific directions in energy saving in three-phase transformers and four-wire lines with asymmetric, non-linear and reactive loads. News of St. Petersburg State Agrarian University, 2(47): 300-309.

[6] Belitsky AA, Shklyarsky YE. (2018) Estimation of additional power losses in networks with non-linear and asymmetric load. Bulletin of Tula State University. Technical Science, 7: 8693.

[7] Wang T, Meskin M, Su X, Grinberg I, Wang Z. (2019) Optimal inverter based distributed generation units control strategy to improve voltage profiles in unbalanced distribution networks. IET Generation, Transmission and Distribution, 13(21): 4910-4921.

[8] Zeng XJ, Zhai HF, Wang MX, Yang M, Wang MQ. (2019) A system optimization method for mitigating three-phase imbalance in distribution network. International Journal of Electrical Power \& Energy Systems, 113: 618-633.

[9] Zhang B, Wang L, Han X, Meng R, Ren C, Wang Q. (2018) Source current control strategy of active power filters for unbalanced load compensation in three-phase four-wire distribution networks. Journal of Power Electronics, 18(5): 1545-1554.

[10] Deokar SA, Waghmare LM. (2011) Analysis of distribution transformer performance un-der non-linear balanced load conditions and it's remedial. International Journal of Technology and Advanced Engineering, 1(2): 152-161.

[11] Corasaniti VF, Barbieri MB, Arnera PL, Valla MI. (2006) Characteristics of the loads in medium voltage networks from the point of view using active filters. In: IEEE PES Transmission and Distribution Conference and Exposition: Latin America (pp. 1-7). 16-19 August, in Caracas, Venezuela. Piscataway: Institute of Electrical and Electronics Engineers.

[12] Barutskov I.B., Vdovenko S.A., Tsygankov E.V. (2011) Harmonic distortion during operation of frequency converters. Chief Power Engineer, 6: 5-13.

[13] Om PM, Abdul GSh. (2016) Topological aspects of power quality improvement techniques: A comprehensive overview. Renewableand Sustainable Energy Reviews, 58: 1129-1142.

[14] Bodart M, Denejer A, Keppens A, Rikart UR, Rojzin B. (2010) Characteristics of compact fluorescent lamps with integrated ballasts and their comparison with incandescent lamps. Lighting Engineering, 2: 18-24.

[15] Suslov KV, Stepanov VS, Solonina NN. (2013) Effect of high harmonics on electricity consumers in distribution networks. Proceedings of the 2013 International Symposium on Electromagnetic Compatibility (EMC Europe 2013): 841-845. 